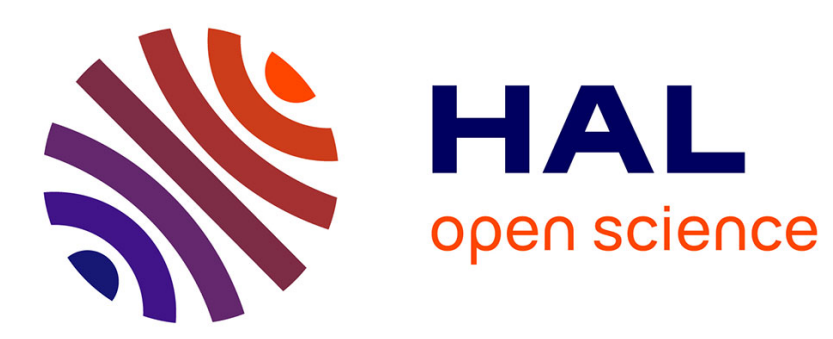

\title{
Modeling of rare earth element sorption to the Gram positive Bacillus subtilis bacteria surface
}

\author{
Raul E. Martinez, Olivier Pourret, Yoshio Takahashi
}

\section{To cite this version:}

Raul E. Martinez, Olivier Pourret, Yoshio Takahashi. Modeling of rare earth element sorption to the Gram positive Bacillus subtilis bacteria surface. Journal of Colloid and Interface Science, 2013, 413, pp.106-111. 10.1016/j.jcis.2013.09.037 . hal-02136372

\section{HAL Id: hal-02136372 \\ https://hal.science/hal-02136372}

Submitted on 22 May 2019

HAL is a multi-disciplinary open access archive for the deposit and dissemination of scientific research documents, whether they are published or not. The documents may come from teaching and research institutions in France or abroad, or from public or private research centers.
L'archive ouverte pluridisciplinaire HAL, est destinée au dépôt et à la diffusion de documents scientifiques de niveau recherche, publiés ou non, émanant des établissements d'enseignement et de recherche français ou étrangers, des laboratoires publics ou privés. 


\title{
Modeling of rare earth element sorption to the Gram positive
}

\section{Bacillus subtilis bacteria surface}

\author{
Raul E. Martinez ${ }^{1, *}$, Olivier Pourret ${ }^{2}$, Yoshio Takahashi $^{3}$
}

\footnotetext{
${ }^{1}$ Insitut für Geo- und Umweltnaturwissenschaften, Albert-Ludwigs Universität, Albertstraße 23b, D-79104, Freiburg, Germany.

${ }^{2}$ HydrISE, Institut Polytechnique LaSalle Beauvais, 19 rue Pierre Waguet, 60026 Beauvais Cedex, France.

${ }^{3}$ Department of Earth and Planetary Systems Science, Hiroshima University, HigashiHiroshima, Hiroshima 739-8526, Japan.
}

*corresponding author

Tel.: +497612036423

E-mail address: raul.martinez@minpet.uni-freiburg.de (R. E. Martinez) 


\section{Abstract}

In this study, rare earth element (REE) binding constants and site concentration on the Gram+ bacteria surfaces were quantified using a multi-site Langmuir isotherm model, along with a linear programming regression method (LPM), applied to fit experimental REE sorption data. This approach found one discrete REE binding site on the Gram+Bacillus subtilis surface for the $\mathrm{pH}$ range of 2.5 to 4.5 . Average $\log _{10}$ REE binding constants for a site $\mathrm{j}$ on these bacteria ranged from $1.08 \pm 0.04$ to $1.40 \pm 0.04$ for the light REE (LREE: La to Eu), and from $1.36 \pm 0.03$ to $2.18 \pm 0.14$ for the heavy REE (HREE: Gd to $\mathrm{Lu}$ ) at the highest biomass concentration of $1.3 \mathrm{~g} / \mathrm{L}$ of Bacillus subtilis bacteria. Similar values were obtained for bacteria concentrations of 0.39 and $0.67 \mathrm{~g} / \mathrm{L}$ indicating the independence of REE sorption constants on biomass concentration. Within the experimental $\mathrm{pH}$ range in this study, Bacillus subtilis was shown to have a lower affinity for LREE (e.g. La, Ce, Pr, Nd) and a higher affinity for HREE (e.g. Tm, Yb, Lu) suggesting an enrichment of HREE on the surface of Gram+ bacteria. Total surface binding site concentrations of $6.73 \pm 0.06$ to $5.67 \pm 0.06$ and $5.53 \pm 0.07$ to $4.54 \pm 0.03$ moles/g of bacteria were observed for LREE and HREE respectively, with the exception of $\mathrm{Y}$, which showed a total site concentration of $9.53 \pm 0.03$, and a $\log \mathrm{K}_{\mathrm{REE}, \mathrm{j}}$ of $1.46 \pm$ 0.02 for a biomass content of $1.3 \mathrm{~g} / \mathrm{L}$. The difference in these values (e.g. a lower affinity and increased binding site concentration for LREE, and the contrary for the HREE) suggests a distinction between the LREE and HREE binding modes to the Gram+ bacteria reactive surface at low $\mathrm{pH}$. This further implies that HREE may bind more than one monoprotic reactive group on the cell surface. A multisite Langmuir isotherm approach along with the LPM regression method, not requiring prior knowledge of the 
number or concentration of cell surface REE complexation sites, were able to distinguish between the sorption constant and binding site concentration patterns of LREE and HREE on the Gram+ Bacillus subtilis surface. This approach quantified the enrichment of $\mathrm{Tm}, \mathrm{Yb}$ and $\mathrm{Lu}$ on the bacteria surface and it has therefore proven to be a useful tool for the study of natural reactive sorbent materials controlling REE partitioning in the natural environment.

Key words: REE, Bacillus subtilis, bacteria, metal sorption, multi-site Langmuir isotherm, linear programming regression 


\section{Introduction}

The solution and mineral properties of rare earth elements (REE) make them adequately robust probes for low temperature geochemical reactions. The interest in REE geochemistry arises from their systematic chemical properties which usually lead to fractionation in geochemical systems [1]. REE form a coherent group and generally occur in the trivalent oxidation state. The effective ionic radii of REE decrease when the atomic number increases [2]. This effect causes characteristic regular features of normalized REE patterns defining the CHArge and RAdius-Controlled process, CHARAC [3]. If a low temperature geochemical system is characterized by a CHARAC pattern, REE of similar charge and radius should display a coherent behavior. This property, however, is no longer observed when chemical processes are driven by an external electronic configuration that produces a sub-partition (non-CHARAC processes). The CHARAC attribute of REE should thus generate smooth, rather than irregular patterns (excepting redox-related $\mathrm{Ce}$ and Eu anomalies) which may indicate non-CHARAC behavior. By studying fractionation trends, it then becomes possible to quantify the underlying REE fractionation processes in the natural environment [3, 4].

In aquatic geochemical systems, REE fractionation takes place through complexation to reactive surface organic [5] and inorganic [6] ligands as well as surface complexation to aquifer minerals [7]. REE have been suggested to be associated with dissolved organic colloids, which play a major role in complexing REE and facilitate their fractionation [8-10]. Reactive surface organic acids have been proposed to be potent 
sorbents of REE. The effects of humic acids on REE fractionation have been previously studied by monitoring the concentration of REE as a function of increasing organic matter (e.g. humic acid) content [11, 12]. At low concentrations of dissolved organic matter, two REE binding sites were found whereas at high levels of humic acids only one site was observed. REE binding in the presence of humic acids was suggested to occur at weak (e.g. carboxylic groups) and strong sites (e.g. phenolic moieties) within the complex structure of dissolved organic matter $[11,13]$.

In recent years, however, there have been very few studies concerned with identifying the patterns of REE association with the bacteria surface [14]. Indeed, bacteria have been recognized as an important substrate regulating the partitioning and mobility of metal ions in natural waters $[15,16]$. In their study, Takahashi et al. [14] observed a peak around the middle of the light REE (LREE) part of the distribution pattern and an anomalous enrichment of heavy REE (HREE) on the bacteria surface, especially for $\mathrm{Tm}, \mathrm{Yb}$, and $\mathrm{Lu}$. In addition, similar characteristics were observed in the REE pattern of a natural microbial mat and a bioflim, suggesting that the HREE enrichment could be a signature of the influence of bacteria in REE immobilization in natural systems $[15,17]$.

The effects of bacteria surface reactivity on REE fractionation were previously studied by monitoring the concentration of REE as a function of various bacteria concentrations under different physico-chemical conditions $[14,17,18]$. Useful approximations to identifying the fractionation patterns on the cell surface can be best 
monitored using adequate surface complexation models to quantify sorption constants and the number of binding sites available for REE complexation. Recent studies have assessed metal binding to bacteria surfaces through the use of chemical equilibrium modeling programs such as the linear programming method (LPM) [19] and FITEQL [20]. These mathematical schemes have been successfully applied to the processing of high resolution metal and proton sorption data from organic ligands, humics, mineral oxides and intact bacterial cells [21-24]. Bacteria metal complexation studies, for the purpose of identifying direct metal cation complexation and biomineralization processes at the atomic scale have also benefited from the use of state-of-the-art spectroscopic techniques such as extended X-ray absorption fine structure (EXAFS) spectroscopy, Xray absorption near edge spectroscopy (XANES), as well as synchrotron FTIR and STXM methods [25-29].

Despite the use of these sophisticated methods, the underlying complexity of the Gram positive and Gram negative bacteria surfaces and the limitation of spectroscopic measurements to high metal concentrations, continue to generate uncertainty in the interpretation of spectroscopic results designed to assess to metal sorption modes on reactive solid surfaces [30]. This suggests that the application of refined surface complexation models to high quality aqueous chemical data, complemented by specific spectroscopic measurements designed to identify the binding modes of metals (e.g. monodentate or bidentate binding) on complicated organic surface, continue to be a more practical first approach for the quantification of metal (e.g. REE) bacteria sorption constants and surface binding site concentrations [31]. In this study, REE bacteria 
sorption data were fitted using a multi-site Langmuir isotherm model and a linear programming regression method (LPM), not requiring a priori assumptions of binding constant and site concentration values, as described previously in detail [11, 19]. Although LPM was applied to the analysis of metal sorption to bacteria, bacteriogenic iron oxides, and humic acids, this method has not yet been employed for the quantification of REE bacteria surface complexation.

\section{Modeling of REE sorption to bacteria surface}

REE-bacteria complexation data, published previously by Takahashi et al. [14], were re-evaluated and modeled in this study, using a multi-site Langmuir isotherm approach along with LPM using simplex search method optimization, as described previously by Martinez et al. [32], and Pourret and Martinez [11]. The total initial REE concentration in the presence of Bacillus subtilis bacteria in Takahashi et al. [14] was 100 $\mu \mathrm{g} / \mathrm{L}$ for all REE. This concentration was achieved from a stock standard solution from Spex CertiPrep., Edison, New Jersey, with a concentration of $10 \mathrm{mg} / \mathrm{L}$ for all REE except Pm. To propose a mechanism for the interaction of REE and protons, within the $\mathrm{pH}$ range of 2.5 to 4.5 , with the bacteria reactive surface, a $\mathrm{REE}^{3+} / \mathrm{H}^{+}$competition reaction was assumed to take place in a 1:1 ratio, as follows:

$$
\mathrm{REE}^{3+}+\mathrm{B}_{\mathrm{j}} \mathrm{H}^{0} \leftarrow^{\mathrm{K}_{\mathrm{REE}, \mathrm{j}}} \rightarrow \mathrm{REE}-\mathrm{B}_{\mathrm{j}}^{2+}+\mathrm{H}^{+}
$$

where, $B_{j}$ represents a bacteria surface reactive site and $K_{R E E, j}$ is the concentration apparent equilibrium constant for the reaction in Eq. (1), conditional on ionic strength. 
For a $\mathrm{j}^{\text {th }}$ deprotonated binding site at the ith step of the acid base titration, $\mathrm{K}_{\mathrm{REE}, \mathrm{j}}$ is defined as:

$$
\mathrm{K}_{\mathrm{REE}, \mathrm{j}}=\frac{\left[\mathrm{REE}-\mathrm{B}_{\mathrm{j}}^{2+}\right]_{\mathrm{i}} \cdot\left[\mathrm{H}^{+}\right]_{\text {meas }, \mathrm{i}}}{\left[\mathrm{REE}^{3+}\right]_{\text {meas }, \mathrm{i}} \cdot\left[\mathrm{B}_{\mathrm{j}} \mathrm{H}^{0}\right]_{\mathrm{i}}}
$$

where $\mathrm{i}=1$ to $\mathrm{n}$ titrant additions and $\mathrm{j}=1$ to $\mathrm{m}$ binding sites. In Eq. (2), $\mathrm{K}_{\mathrm{REE}, \mathrm{j}}$ implicitly includes electrostatic parameters and is a function of proton concentration, derived from experimentally measured proton activity at $0.01 \mathrm{M} \mathrm{NaCl}$, and determined REE concentrations, $\left(\left[\mathrm{H}^{+}\right]_{\text {meas }, \mathrm{i}}\right.$ and $\left.\left[\mathrm{REE}^{3+}\right]_{\text {meas,i }}\right)$ and of the amount of $\mathrm{REE}^{3+}$ bound to the $\mathrm{j}^{\text {th }}$ bacteria surface site at the $i^{\text {th }}$ step of an acid base titration, $\left[\text { REE- } B_{j}{ }^{2+}\right]_{i}$. From mass balance calculations, the total bound REE at the $\mathrm{i}^{\text {th }}$ titrant addition or $\mathrm{pH}$ value, [REE$\left.\mathrm{B}^{+}\right]_{\mathrm{T}, \mathrm{i}}$, and the total ligand concentration (e.g. total binding site density), $[\mathrm{B}]_{\mathrm{T}}$ can be expressed as:

$$
\left[\operatorname{REE}-\mathrm{B}^{2+}\right]_{\mathrm{T}, \mathrm{i}}=\sum_{\mathrm{j}=1}^{\mathrm{m}}\left[\mathrm{REE}-\mathrm{B}_{\mathrm{j}}^{2+}\right]_{\mathrm{i}}=\left[\mathrm{REE}^{3+}\right]_{\mathrm{T}}-\left[\mathrm{REE}^{3+}\right]_{\text {meas }, \mathrm{i}}
$$

and

$$
[B]_{T}=\sum_{j=1}^{m}\left[B_{j}\right]=\left[R E E-B^{2+}\right]_{T, i}+\sum_{j=1}^{m}\left[B_{j} H^{0}\right]_{i}
$$

where $\left[\mathrm{B}_{\mathrm{j}}\right]$ refers to the individual site concentration for a particular bacteria surface reactive group. The total amount of REE bound, $\left[\text { REE- } B^{2+}\right]_{T, i}$, can be expressed as the sum of complexed REE for each of the $\mathrm{j}^{\text {th }}$ bacteria surface sites at the $\mathrm{i}^{\text {th }} \mathrm{pH}$ value (e.g. $\left[R E E-B^{2+}\right]_{T, i}=\sum_{j=1}^{m}\left(\left[R E E-B_{j}^{2+}\right]_{i}\right)$. However, experimental measurements of total, 
$\left[\mathrm{REE}^{3+}\right]_{\mathrm{T}}$ and free REE concentrations $\left[\mathrm{REE}^{3+}\right]_{\text {meas, }}$, only allow direct determination of $\left[\text { REE- } \mathrm{B}^{2+}\right]_{\mathrm{T}, \mathrm{i}}$, as shown in Eq. (3).

The fraction of the total $\mathrm{j}^{\text {th }}$ ligand concentration, bound by the REE cation at the ith step of the titration, $\alpha_{\mathrm{REEB}_{, \mathrm{ij}}}$, can be expressed as a function of the bound REE at the $\mathrm{i}^{\text {th }}$ titrant addition, $\left[\mathrm{REE}-\mathrm{B}_{\mathrm{j}}^{2+}\right]_{\mathrm{i}}$ and the $\mathrm{j}^{\text {th }}$ ligand concentration, $\left[\mathrm{B}_{\mathrm{j}}\right]$ as follows:

$$
\alpha_{\text {REEB }, i j}=\frac{\left[R E E-B_{j}^{2+}\right]_{i}}{\left[B_{j}\right]}=\frac{\left[R E E-B_{j}^{2+}\right]_{i}}{\left[R E E-B_{j}^{2+}\right]_{i}+\left[B_{j} H^{0}\right]_{i}}
$$

The protonated $j^{\text {th }}$ ligand concentration at the $i^{\text {th }}$ step of the titration, $\left[\mathrm{B}_{\mathrm{j}} \mathrm{H}^{0}\right]_{\mathrm{i}}$ can be then expressed as a function of $\left[\mathrm{REE}-\mathrm{B}_{\mathrm{j}}^{2+}\right]_{\mathrm{i}}$, by rearranging the expression for the equilibrium constant $K_{R E E, j}$ in Eq. (2). The calculated bound REE concentration at the $i^{\text {th }}$ titrant addition, $\left[\mathrm{REE}-\mathrm{B}^{2+}\right]_{\mathrm{T}, \mathrm{calc}, \mathrm{i}}$, can be determined as a function of measured, $\left(\left[\mathrm{H}^{+}\right]_{\text {meas, } \mathrm{i}}\right.$ and $\left.\left[\operatorname{REE}^{3+}\right]_{\text {meas, }}\right)$ and adjustable $\left(\left[\mathrm{B}_{\mathrm{j}}\right]\right)$ parameters:

$$
\left[\operatorname{REE}-\mathrm{B}^{2+}\right]_{\mathrm{T}, \text { calc }, \mathrm{i}}=\sum_{\mathrm{j}=1}^{\mathrm{m}}\left(\alpha_{\mathrm{REEB}, \mathrm{ij}} \cdot\left[\mathrm{B}_{\mathrm{j}}\right]\right)=\sum_{\mathrm{j}=1}^{\mathrm{m}} \frac{\left[\mathrm{REE}^{3+}\right]_{\text {meas }, \mathrm{i}} \cdot \mathrm{K}_{\mathrm{REE}, \mathrm{j}}}{\left[\operatorname{REE}^{3+}\right]_{\text {meas }, \mathrm{i}} \cdot \mathrm{K}_{\mathrm{REE}, \mathrm{j}}+\left[\mathrm{H}^{+}\right]_{\text {meas }, \mathrm{i}}} \cdot\left[\mathrm{B}_{\mathrm{j}}\right]
$$

The linear programming approach to solving chemical equilibrium problems for multi-site REE sorption is based on solving a matrix equation $\vec{b}=A \cdot \vec{x}$ for $\vec{x}$. Here $A$ is an $\mathrm{n} x \mathrm{~m}$ matrix of $\alpha_{\mathrm{REEB}, \mathrm{ij}}$ entries as defined in Eqs. (5) and (6). $\overrightarrow{\mathrm{b}}$ is a $\mathrm{n} x 1$ vector of calculated bound REE concentrations for each titrant addition ( $\mathrm{pH}$ value), 
$\left[\text { REE }-\mathrm{B}^{2+}\right]_{T, \text { calc, }}$, as defined in Eq. (6). The $\mathrm{m} x 1$ vector $\overrightarrow{\mathrm{x}}$ contains the adjustable parameters, $\left[\mathrm{B}_{\mathrm{j}}\right]$, for each of the $\mathrm{m}$ binding sites.

As stated previously by Brassard et al. [19] and Martinez et al. [21, 32], numerical difficulties appear when fitting the model in Eq. (6) because REE binding constants and site concentrations are correlated parameters. In order to solve the correlation problem, a fixed interval grid of $\log \mathrm{K}_{\mathrm{REE}, \mathrm{j}}$ values was used when writing the problem in matrix form, as described by Brassard et al. [19]. In addition, more than one error minimum can be found from the optimization for $\vec{x}$ as a solution to the equation $\vec{b}=A \cdot \vec{x}$, unless further assumptions are made about the nature of the solution, as mentioned previously [19].

Linear programming regression along with a simplex search method minimize the number of REE binding sites and the absolute error, $\mathrm{e}=\left|\left[\mathrm{REE}-\mathrm{B}^{2+}\right]_{\mathrm{T}, \text { calc,i }}\left[\operatorname{REE}-\mathrm{B}^{2+}\right]_{\mathrm{T}, \mathrm{i}}\right|$, rather than the least squares [19]. This procedure finds one global minimum for the error function, which emphasizes zero as a possible solution and avoids convergence problems as mentioned previously [19, 21]. LPM uses a grid of fixed $\log \mathrm{K}_{\mathrm{REE}, \mathrm{j}}$ values and optimizes the total binding site concentrations (TSC). Each site density, $\left[\mathrm{B}_{\mathrm{j}}\right]$, is assigned a positive value where zero is a possible result. This mathematical routine generates a log $\mathrm{K}_{\mathrm{REE}, \mathrm{j}}$ spectrum where discrete metal binding sites are determined by the number of $\log \mathrm{K}_{\mathrm{REE}, \mathrm{j}}$ values, which have a corresponding nonzero REE binding site density. When $\left[\mathrm{B}_{\mathrm{j}}\right]$ values are added, their sum should approximate the 
total available ligand concentration on the bacteria reactive surface, $[\mathrm{B}]_{\mathrm{T}}$, for a maximum experimental $\mathrm{pH}$ value (e.g. $\mathrm{pH}=4.5$ in this study) [19].

\section{Results and discussion}

Tables 1 and 2, and Figs. 1, 2 and 3, summarize LPM optimization results of log $\mathrm{K}_{\mathrm{REE}, \mathrm{j}}$ and $[\mathrm{B}]_{\mathrm{T}}$ as defined by Equations 2 and 4 respectively for measured $\left[\mathrm{REE}^{3+}\right]$ sorption at three different Bacillus subtilis concentrations of $0.39,0.67$ and $1.3 \mathrm{~g} / \mathrm{L}$, in the $\mathrm{pH}$ range of 2.5 to 4.5 . Tables 1 and 2 show the $\log \mathrm{K}_{\mathrm{REE}, \mathrm{j}}$ and $[\mathrm{B}]_{\mathrm{T}}$ values for all REE elements at the full range of bacteria concentrations. As observed by the results in Tables 1 and 2, optimization of REE-bacteria sorption data using a multi-site Langmuir isotherm and the LPM approach generated a unique binding site density corresponding to a single $\log K_{\mathrm{REE}, \mathrm{j}}$ value for each $\mathrm{REE}$ on an initially set $\log \mathrm{K}_{\mathrm{REE}, \mathrm{j}}$ grid where, prior to optimization, a value of zero binding site concentration, (i.e. $\left[\mathrm{B}_{\mathrm{j}}{ }^{-}\right]$) was assigned to each $\log \mathrm{K}_{\mathrm{REE}, \mathrm{j}}$. However, double peaks resulted for a number of sites $\mathrm{j}$ (data not shown), because the true $\log \mathrm{K}_{\mathrm{REE}, \mathrm{j}}$ generated from the fit of a particular data set fell at an intermediate position between two adjacent $\log \mathrm{K}_{\mathrm{REE}, \mathrm{j}}$ on the grid [32]. Each doublet was converted to a single peak by averaging the two $\log K_{R E E, j}$ values (Table 1) and computing the weighted average of $\left[\mathrm{B}_{\mathrm{j}}^{-}\right]$. These averaged values, along with existing single peaks, in replicate spectra were used to calculate overall log $\mathrm{K}_{\mathrm{REE}, \mathrm{j}}$ and total REE binding site concentrations (Table 2). 

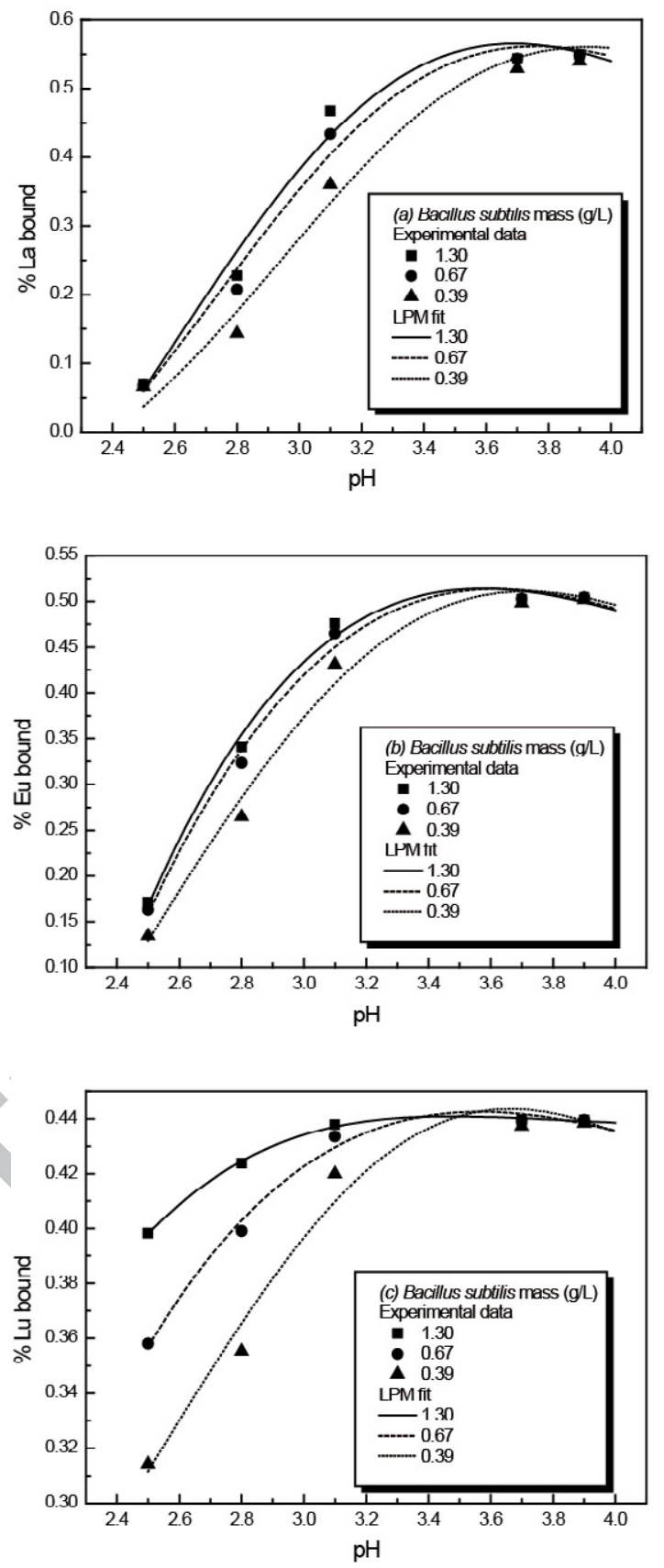

Figure 1

The average $\log \mathrm{K}_{\mathrm{REE}, \mathrm{j}}$ and binding site densities obtained for the three Bacillus subtilis concentrations are reported in Tables 1 and 2, for the 14 analyzed REE 
respectively. An example of the LPM fit resulting from the optimization of experimental REE-bacteria sorption data, as a function of increasing $\mathrm{pH}$, are depicted in Figure 1 for $\mathrm{La}^{3+}, \mathrm{Eu}^{3+}$ and $\mathrm{Lu}^{3+}$. Sample $\log \mathrm{K}_{\mathrm{REE}, \mathrm{j}}$ values for $\mathrm{La}^{3+}$ are $0.85 \pm 0.02,1.03 \pm 0.04$ and $1.08 \pm 0.04$ for bacteria concentrations of $0.39 \mathrm{~g} / \mathrm{L}, 0.67 \mathrm{~g} / \mathrm{L}$ and $1.3 \mathrm{~g} / \mathrm{L}$ respectively. For the same biomass concentrations, $\mathrm{Eu}^{3+}$ and $\mathrm{Lu}^{3+}$ show $\log \mathrm{K}_{\mathrm{REE}, \mathrm{j}}$ of $1.22 \pm 0.03,1.36 \pm 0.03$ and $1.40 \pm 0.03$; and $1.77 \pm 0.16,2.16 \pm 0.02$ and $2.18 \pm 0.14$ respectively (Figure 1). With the exception of the lowest biomass condition (i.e., $0.39 \mathrm{~g} / \mathrm{L}$ ), the $\log \mathrm{K}_{\mathrm{REE}, \mathrm{j}}$ values remain constant within uncertainty at higher Bacillus subtilis concentrations of $0.67 \mathrm{~g} / \mathrm{L}$ and $1.3 \mathrm{~g} / \mathrm{L}$. Moreover, at biomass concentrations of $0.67 \mathrm{~g} / \mathrm{L}, \log \mathrm{K}_{\mathrm{REE}, \mathrm{j}}$ values increase from $\mathrm{La}(1.03)$ to $\mathrm{Eu}$ (1.36), then decrease from $\mathrm{Eu}$ (1.36) to Ho (1.28) and further increase to 2.16 for Lu. This feature is further marked for a higher Bacillus subtilis concentration (i.e., $1.3 \mathrm{~g} / \mathrm{L}$ ) where $\log \mathrm{K}_{\mathrm{REE}, \mathrm{j}}$ values increase from $\mathrm{La}$ (1.08) to $\mathrm{Eu}(1.40)$, remain constant from $\mathrm{Gd}$ to Ho (1.36), and increase from Ho (1.36) to $\mathrm{Lu}$ (2.18). These results of REE bacteria surface binding constants may suggest a pattern showing a middle REE (i.e., Eu to Ho) downward concavity (Fig. 2) as observed previously for interactions of rare earth elements with humic acids [11]. As already proposed by Pourret et al. [12], literature compilation of REE-organic ligand constants $[6,33]$ as plotted against $\mathrm{Gd} / \mathrm{Yb}$ ratio (Fig. 4) evidenced that calculated log $K_{\text {REE,j }}$ values in this study are in the range of natural carboxylic acids. However, associated $\mathrm{Gd} / \mathrm{Yb}$ ratios evidence HREE enrichment not observed for these natural carboxylic acids. Furthermore, as determined previously by Martinez et al. [34], and references therein, the identity of deprotonating functional groups on the Bacillus subtilis surface should correspond, for the most part, to carboxylic groups within the $\mathrm{pH}$ range in this study. Variations in REE-bacteria surface sorption 
patterns may arise due to differences in binding modes of REE-COO complexation [6]. The higher $\log \mathrm{K}_{\mathrm{REE}, \mathrm{j}}$ values for Tm to $\mathrm{Lu}$ at $0.67 \mathrm{~g} / \mathrm{L}$ and $1.3 \mathrm{~g} / \mathrm{L}$ of bacteria provide robust evidence for a potential enrichment of these elements on the bacteria surface.

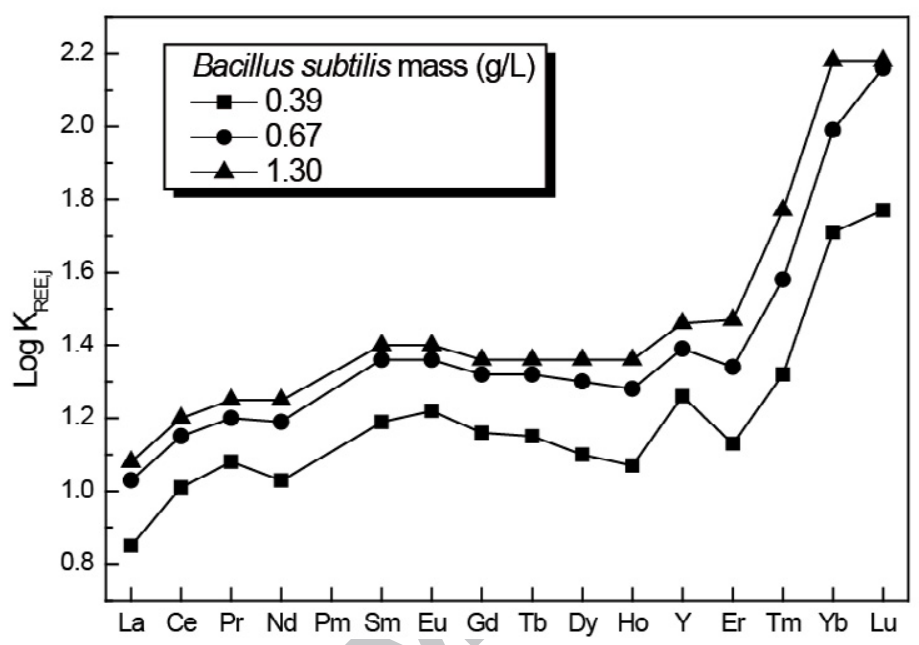

Figure 2

As shown in Table 1 , one $\log \mathrm{K}_{\mathrm{REE}, \mathrm{j}}$ value was found by LPM for each bacteria concentrations of $0.39 \mathrm{~g} / \mathrm{L}, 0.67 \mathrm{~g} / \mathrm{L}$ and $1.3 \mathrm{~g} / \mathrm{L}$. This feature reflects the heterogeneity of the bacteria surface and is in agreement with the presence of a single deprotonating carboxylic functional group, at the highest $\mathrm{pH}$ of 4.5 in this study [34]. This latter characteristic and the range of $\log \mathrm{K}_{\mathrm{REE}, \mathrm{j}}$ values in Table 1 for all bacteria concentrations, further suggest the presence of different modes of surface complexation by each of the REE. The observed difference in $\log \mathrm{K}_{\mathrm{REE}, \mathrm{j}}$ may be indicative of MREE (e.g. Eu) and HREE (e.g. Lu) enrichment on the bacteria surface, as $\log \mathrm{K}_{\mathrm{REE}, \mathrm{j}}$ values increase by 130 and $160 \%$ respectively with respect to, for example, La and $\mathrm{Gd}$ with observed $\log \mathrm{K}_{\mathrm{REE}, \mathrm{j}}$ of $1.08 \pm 0.04$ and $1.36 \pm 0.03$ at highest bacteria concentrations of $1.3 \mathrm{~g} / \mathrm{L}$. Increasing 
$\log K_{R E E, j}$ are indicative of stronger binding of REE to the bacteria surface and of the presence of more than one metal-ligand complexation process, such as monodentate or bidentate complexation, as suggested previously for other metal cations [32].

Recent studies calculated REE sorption constants, $\mathrm{K}_{\mathrm{m}}$, for REE complexation by bacteria surface functional groups, defined as $\mathrm{K}_{\mathrm{m}}=\left[\mathrm{REE}^{\mathrm{B}} \mathrm{B}^{2+}\right] /\left[\mathrm{REE}^{3+}\right][\mathrm{B}]$ at fixed $\mathrm{pH}$ values using FITEQL ${ }^{\circledR}\left[18,24,33\right.$ ]. Fein et al. [35] calculated a $\log \mathrm{K}_{\mathrm{m}}$ of 5.1 for monodentate $\mathrm{Nd}$ adsorption to carboxyl sites on Bacillus subtilis cells at a fixed $\mathrm{pH}$ of 5.3 \pm 0.3 , close to that of 5.06 in Ngwenya et al. [24]. Conversely, Markai et al. [18] determined a $\log \mathrm{K}_{\mathrm{m}}$ value of 7.13 or 5.97 for Eu-carboxyl complexing on Bacillus subtilis cells, whereas a $\log \mathrm{K}_{\mathrm{m}}$ of 4.83 was proposed by Ngwenya et al. [24]. Moreover, Markai et al. [18] and Ngwenya et al. [24] also suggested sorption constants for Eu binding to phosphate reactive sites of 8.14 and 7.97 respectively. Modeling of REE binding constants at higher $\mathrm{pH}$ (e.g. 6 to 6.5 ) as proposed by Markai et al. [18] and Ngwenya et al. [24] should take into account REE speciation, since at more alkaline $\mathrm{pH}$ values (e.g. $\mathrm{pH}>5$ ), $\mathrm{REE}$ can be strongly complexed by dissolved anions including: $\mathrm{F}$, $\mathrm{SO}_{4}{ }^{2-}$ and $\mathrm{PO}_{4}{ }^{3-}$. This would affect the proportion of dissolved REE able to interact with cell surface deprotonated reactive groups and in turn the calculation of the respective binding constants.

In this study, equilibrium constants for REE sorption to the Bacillus subtilis surface were determined as per Eqs. (1) and (2) implying a competition of $\mathrm{REE}^{3+}$ and $\mathrm{H}^{+}$ for bacteria surface binding sites. $\mathrm{K}_{\mathrm{REE}, \mathrm{j}}$ can be expressed, therefore, as $\mathrm{K}_{\mathrm{REE}, \mathrm{j}}=\mathrm{K}_{\mathrm{m}} x \mathrm{~K}_{\mathrm{a}}$ 
or $\log \mathrm{K}_{\mathrm{REE}, \mathrm{j}}=\log \mathrm{K}_{\mathrm{m}}+\log \mathrm{K}_{\mathrm{a}}$, where $\mathrm{K}_{\mathrm{m}}$ is the equilibrium constant for REE binding to the bacteria surface independent of $\mathrm{pH}$ as defined above, and $\mathrm{K}_{\mathrm{a}}$ is the acid dissociation constant for the deprotonation of a bacteria surface functional groups defined as described previously by Eq. (2) in Martinez et al. [32]. Log $K_{m}$ values were calculated in this study as $\log \mathrm{K}_{\mathrm{m}}=\log \mathrm{K}_{\mathrm{REE}, \mathrm{j}}-\log \mathrm{K}_{\mathrm{a}}$, where $\log \mathrm{K}_{\mathrm{a}}$ was established at $3.59 \pm 0.38$ as determined earlier by LPM optimization in Martinez et al. [32]. An example of the results for the $\log \mathrm{K}_{\mathrm{m}}$ calculations for each REE are shown in Table 1 for the highest bacteria biomass of $1.3 \mathrm{~g} / \mathrm{L}$. These values range from $4.67 \pm 0.38$ to $5.77 \pm 0.41$ and are in good agreement with those calculated by previous researchers $[18,24,33]$. This is rather robust evidence to confirm the validity of the LPM method for the calculation of REE sorption constants on the Gram+ bacteria surface without the need of a priori assumptions on the number and concentration of reactive sites [11, 19, 21, 23, 31, 32].

Even if the modelling approach in this study only considered monodentate sites, an interesting feature would be evidenced for the three Bacillus subtilis bacteria concentrations used. As shown in Table 2, the total binding site concentrations (TSC) arising for the single REE sorption sites in Table 1, are in close agreement for each bacteria mass, allowing the calculation of average TSC for each REE (Table 2). This result confirms the independent character of site concentration on bacterial biomass in $\mathrm{g} / \mathrm{L}$, and validates the LPM approach, as the TSC is not correlated to increasing biomass. In addition and with the exception of $\mathrm{Y}$, the observed decrease in TSC from the LREE $(6.73 \pm 0.06 \mathrm{moles} / \mathrm{g}$ for La) to the HREE $(4.54 \pm 0.03 \mathrm{moles} / \mathrm{g}$ for $\mathrm{Lu})$ suggests different REE-bacteria surface binding modes and a multi-dentate binding of REE to the surface 
functional groups. In other words, REE complexation to two monodentate binding sites would result in lower total site densities available to complex the REE, as compared to a single binding site. The decrease in total site concentration (TSC) as shown in Table 2 and Fig. 3, strongly supports this argument and further implies a mechanism of HREE enrichment (i.e. stronger binding of $\mathrm{Tm}, \mathrm{Yb}$ and $\mathrm{Lu}$ ) on the Gram+ Bacillus subtilis surface via a non monodentate binding. Albeit not considered in this study, multidentate binding may also become important with increasing $\mathrm{pH}$, however the speciation of the LREE and HREE at higher pH values should then be taken into consideration [24].

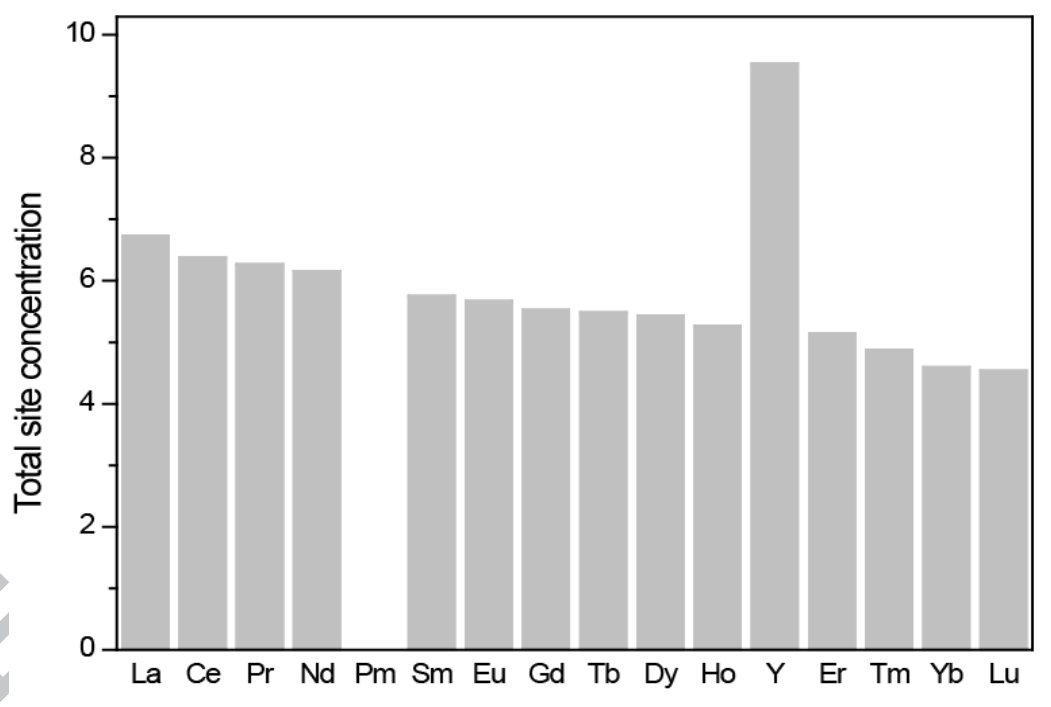

\section{Figure 3}

As evidenced by Table 2 and Fig. 3, the total site density decreases from a maximum value of $6.73 \pm 0.06$ moles $/ g$ for $\mathrm{La}(\mathrm{LREE})$ to $4.54 \pm 0.03 \mathrm{moles} / \mathrm{g}$ for $\mathrm{Lu}$ (HREE). The gradual decrease in TSC through the REE series, with the exception of Y, may thus reflect the competition in between REE, which could be responsible for the 
fractionation within the REE series. $\log \mathrm{K}_{\mathrm{REE}, \mathrm{j}}$ values are a maximum for $\mathrm{Sm}^{3+}$ and $\mathrm{Eu}^{3+}$ (MREE) and $\mathrm{Tm}^{3+}, \mathrm{Yb}^{3+}$ and $\mathrm{Lu}^{3+}$ in the HREE. A similar, but opposite pattern is observed for binding site densities (Table 2 and Fig. 3). This may be the result of a change in the REE coordination number of REE complexes in solution, which ranges from 9 to 8, usually becoming apparent in the $\mathrm{Eu}^{3+}$ to $\mathrm{Gd}^{3+}$ range. The number of water molecules about the inner REE sphere is 9 from $\mathrm{La}^{3+}$ to $\mathrm{Nd}^{3+}$, and 8 from $\mathrm{Tb}^{3+}$ to $\mathrm{Lu}^{3+}$ [36]. From a thermodynamic stand point, the free energy of REE coordination changes in the $\mathrm{Eu}^{3+}$ to $\mathrm{Gd}^{3+}$ range as a result of a the sudden change in the mode of REE surface coordination. Indeed, Choppin and Peterman [37] pointed out that Eu-acetate complexes by an inner sphere mechanism and as acetate represents a model molecule for simple carboxylic sites on complex organic matter such as humic substances or bacteria, such a coordination number change must be expected in the $\mathrm{Eu}^{3+}$ to $\mathrm{Gd}^{3+}$ range when assessing the binding of REE to the bacteria surface. Differences in coordination numbers and modes of REE-surface complexation are induced by variations of inter electronic repulsive potentials, caused by the progressive filling of the $4 f$ orbital during structural changes that especially involve the inner coordination sphere of each REE. These structural changes are the result of equilibrium ligand exchange reactions (e.g., organic phase-aqueous phase equilibrium). Indeed, when processes involve REE adsorption (or surface complexation) with an inner sphere mechanism, a non-CHARAC effect may take place. The complexation behaviour of REE does not thus exclusively depend on its ionic charge and radius, but is additionally controlled by its electron configuration and by the type of complexing ligand, since both of these properties determine the character of the chemical bonding. Hence, aqueous systems are characterized by non-CHARAC trace 
element behavior [3], and electron structure must be considered as an additional parameter. However, such behavior needs to be further explored and refined.

As proposed by Ngwenya et al. [24], fulvic acid may provides reasonable estimates of the stability constants for carboxyl complexation on bacterial surfaces. Moreover, as discussed by Pourret et al. [12] and Marsac et al. [13] observed differences between experiments presented by Takahashi et al. [38], Yamamoto et al. [39, 40], Sonke and Salters [41], strongly suggest the heterogeneity of the complexing sites in HS: high concentration of weak carboxylic sites and low concentrations of strong phenolic sites [42]. However, in the presence of the Gram+ bacteria surface, the weak carboxylic sites determined the behavior of REE complexation and enrichment. Indeed, the $\mathrm{pH}$ range in this study spans from 2.5 to 4.5 , for the bacteria surface, whereas in Yamamoto et al. [39, 40] experimental $\mathrm{pH}$ varies between 4 and 5.5 and, in Sonke and Salters [41] and Stern et al. [43] it varies between 6 and 10 in the presence, however, of humic substances. Nevertheless, the present study sheds more light on the processes dealing with REE enrichment by Gram+ bacteria surface groups and this needs to be extended to further existing data on REE-bacteria complexation with LPM to generalize this feature. In addition, the results in this study, suggest that the multi functionality of the bacteria surface should be taken into account in speciation studies and calculation codes at extended $\mathrm{pH}$ ranges, to quantify the full capabilities of bacteria surface to complex REE.

Stability constants, $\mathrm{K}_{\mathrm{m}}$, calculated for adsorption of REE on the bacterial surface are in the range of natural carboxylate sites (Fig. 4). Thus, carboxylic functional groups 
on the bacteria surface are likely to exert important controls on the REE mobility, cycling, and fractionation in the environment. Indeed, LPM modeling would be of interest as a tool for the better quantification of REE mobility if integrated in a wider models coupled with inorganic speciation [4], surface complexation with organic matter [11] and iron and manganese oxyhydroxide [7].

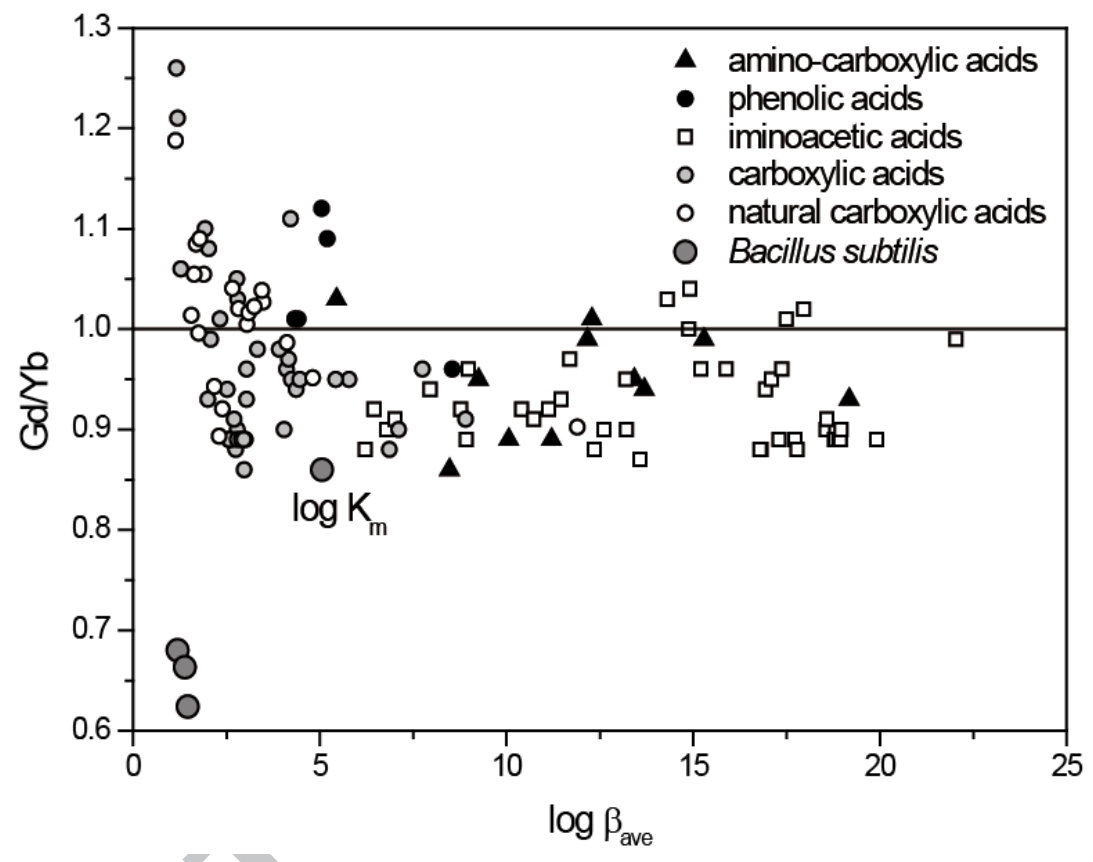

Figure 4

\section{Concluding remarks}

Linear programming modelling was able to quantify differences in REE bacteria surface sorption as a function of increasing Bacillus subtilis concentration. Within the $\mathrm{pH}$ range in this study, REE binding to a single site on the bacteria surface, as determined by LPM, was assumed to take place at carboxylic groups. Moreover, this study has been able to quantify REE-bacteria surface interactions, including the enrichment of HREE on the 
cell surface, the decrease in total REE binding site density from the LREE to the HREE congruent with the proposition of multi-dentate binding to the bacteria surface. In addition, the LPM approach served to the determination of metal binding constants and site concentrations without the need for initial knowledge of these parameters, indicating the usefulness of this approach to solving surface REE complexation in the presence of complex organic surfaces, such as bacteria cells $[19,32]$.

\section{Acknowledgements}

The authors thank the Institute for Earth and Environmental Science, at the University of Freiburg for providing research funding for this project to RM and the Geologists Rock! Group in Beauvais for insightful discussion at the start of this project. 


\section{Figure Captions}

Figure 1. Binding of (a) La, (b) Eu, and (c) Lu to Bacillus subtilis bacteria concentrations (i.e. $0.39,0.67$ and $1.3 \mathrm{~g} / \mathrm{L}$ ) as a function of $\mathrm{pH}$. Points correspond to experimental data [14], and solid lines correspond to the LPM fits.

Figure 2. $\log K_{R E E, j}$ patterns for the 14 rare earth elements.

Figure 3. Site concentration distribution (in mol of $\mathrm{REE}^{3+} / \mathrm{g}$ of Bacillus subtilis bacteria) for the 14 REE (data are from Table 2).

Figure 4. Literature compilation of REE-organic ligand constants (recalculated at $I=0.1$ $\mathrm{mol} / \mathrm{L}$ when necessary; $[6,33])$. black triangles: amino-carboxylic acids; white squares: iminoacetic acids; black circles: phenolic acids; grey circles: carboxylic acids; white circles: natural carboxylic acids: dark grey circles: Bacillus subtilis. 


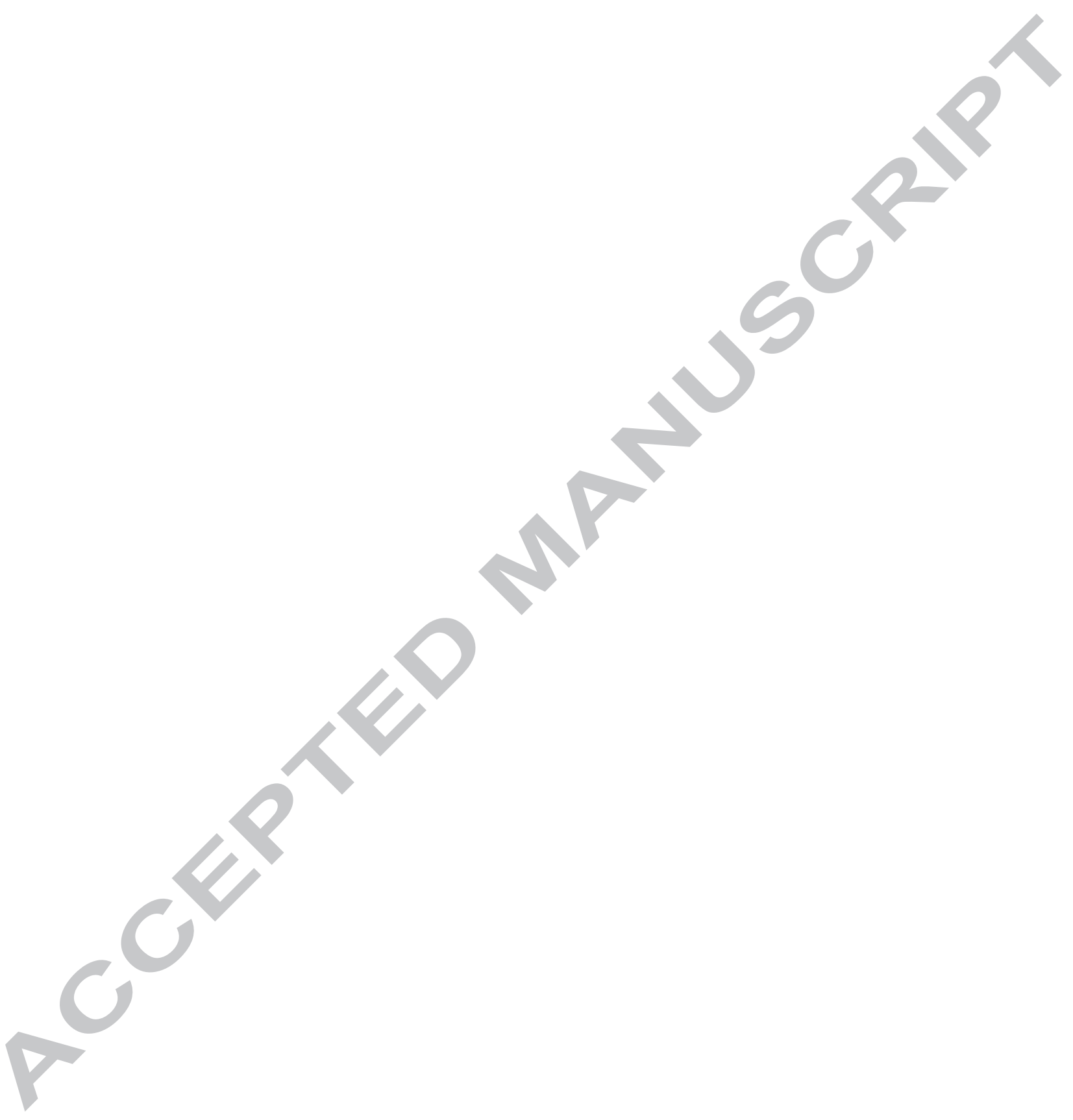




\section{Table 1}

Log $\mathrm{K}_{\mathrm{REE}, \mathrm{j}}$ values for REE as a function of Bacillus subtilis biomass*

\begin{tabular}{|c|c|c|c|c|}
\hline \multirow{2}{*}{ REE } & \multicolumn{4}{|c|}{ Bacillus subtilis mass (g/L) } \\
\hline & 0.39 & 0.67 & 1.3 & $1.3 * *\left(\log \mathbf{K}_{\mathbf{m}}\right)$ \\
\hline $\mathrm{La}$ & $0.85 \pm 0.02$ & $1.03 \pm 0.04$ & $1.08 \pm 0.04$ & $4.67 \pm 0.38$ \\
\hline $\mathrm{Ce}$ & $1.01 \pm 0.02$ & $1.15 \pm 0.02$ & $1.20 \pm 0.02$ & $4.79 \pm 0.38$ \\
\hline $\operatorname{Pr}$ & $1.08 \pm 0.03$ & $1.20 \pm 0.03$ & $1.25 \pm 0.02$ & $4.84 \pm 0.38$ \\
\hline $\mathrm{Nd}$ & $1.03 \pm 0.02$ & $1.19 \pm 0.02$ & $1.25 \pm 0.02$ & $4.84 \pm 0.38$ \\
\hline $\mathrm{Sm}$ & $1.19 \pm 0.02$ & $1.36 \pm 0.03$ & $1.40 \pm 0.03$ & $4.99 \pm 0.38$ \\
\hline $\mathrm{Eu}$ & $1.22 \pm 0.03$ & $1.36 \pm 0.03$ & $1.40 \pm 0.03$ & $4.99 \pm 0.38$ \\
\hline $\mathrm{Gd}$ & $1.16 \pm 0.03$ & $1.32 \pm 0.02$ & $1.36 \pm 0.03$ & $4.95 \pm 0.38$ \\
\hline $\mathrm{Tb}$ & $1.15 \pm 0.02$ & $1.32 \pm 0.02$ & $1.36 \pm 0.03$ & $4.95 \pm 0.38$ \\
\hline Dy & $1.10 \pm 0.02$ & $1.30 \pm 0.03$ & $1.36 \pm 0.03$ & $4.95 \pm 0.38$ \\
\hline Ho & $1.07 \pm 0.02$ & $1.28 \pm 0.02$ & $1.36 \pm 0.03$ & $4.95 \pm 0.38$ \\
\hline $\mathrm{Y}$ & $1.26 \pm 0.03$ & $1.39 \pm 0.02$ & $1.46 \pm 0.02$ & $5.05 \pm 0.38$ \\
\hline Er & $1.13 \pm 0.02$ & $1.34 \pm 0.03$ & $1.47 \pm 0.04$ & $5.06 \pm 0.38$ \\
\hline $\mathrm{Tm}$ & $1.32 \pm 0.03$ & $1.58 \pm 0.03$ & $1.77 \pm 0.04$ & $5.36 \pm 0.38$ \\
\hline $\mathrm{Yb}$ & $1.71 \pm 0.07$ & $1.99 \pm 0.09$ & $2.18 \pm 0.14$ & $5.77 \pm 0.41$ \\
\hline $\mathrm{Lu}$ & $1.77 \pm 0.16$ & $2.16 \pm 0.02$ & $2.18 \pm 0.14$ & $5.77 \pm 0.41$ \\
\hline
\end{tabular}

*Single binding REE binding site found between $\mathrm{pH}$ values of 2.5 to 4.5 , as shown in text.

** $\log \mathrm{K}_{\mathrm{m}} \mathrm{REE}$ carboxyl group binding constant results, as explained in text. 
Table 2

Total site density (in mol of $\mathrm{REE}^{3+} / \mathrm{mg}$ of bacteria)

\begin{tabular}{|c|c|c|c|c|}
\hline \multirow{2}{*}{ REE } & \multicolumn{4}{|c|}{$\begin{array}{l}\text { Bacillus subtilis surface total binding site density } \\
\text { (TSD) as a function of biomass (moles/g) } \times 10^{-7}\end{array}$} \\
\hline & 0.39 & 0.67 & 1.3 & Average TSD** \\
\hline $\mathrm{La}$ & 6.80 & 6.70 & 6.69 & $6.73 \pm 0.06$ \\
\hline $\mathrm{Ce}$ & 6.43 & 6.35 & 6.35 & $6.38 \pm 0.04$ \\
\hline $\operatorname{Pr}$ & 6.28 & 6.26 & 6.26 & $6.27 \pm 0.01$ \\
\hline $\mathrm{Nd}$ & 6.26 & 6.11 & 6.10 & $6.16 \pm 0.08$ \\
\hline $\mathrm{Sm}$ & 5.85 & 5.73 & 5.69 & $5.76 \pm 0.08$ \\
\hline $\mathrm{Eu}$ & 5.74 & 5.65 & 5.62 & $5.67 \pm 0.06$ \\
\hline $\mathrm{Gd}$ & 5.61 & 5.50 & 5.48 & $5.53 \pm 0.07$ \\
\hline $\mathrm{Tb}$ & 5.56 & 5.43 & 5.47 & $5.49 \pm 0.07$ \\
\hline Dy & 5.50 & 5.34 & 5.48 & $5.44 \pm 0.08$ \\
\hline Ho & 5.33 & 5.27 & 5.20 & $5.27 \pm 0.06$ \\
\hline $\mathrm{Y}$ & 9.54 & 9.56 & 9.50 & $9.53 \pm 0.03$ \\
\hline $\mathrm{Er}$ & 5.29 & & 5.05 & $5.11 \pm 0.07$ \\
\hline $\mathrm{Tm}$ & 4.95 & & 4.80 & $4.88 \pm 0.07$ \\
\hline $\mathrm{Yb}$ & 4.65 & 4.60 & 4.53 & $4.59 \pm 0.06$ \\
\hline $\mathrm{Lu}$ & 4.56 & 4.50 & 4.56 & $4.54 \pm 0.03$ \\
\hline
\end{tabular}

**Average total site density on Bacillus subtilis surface. 

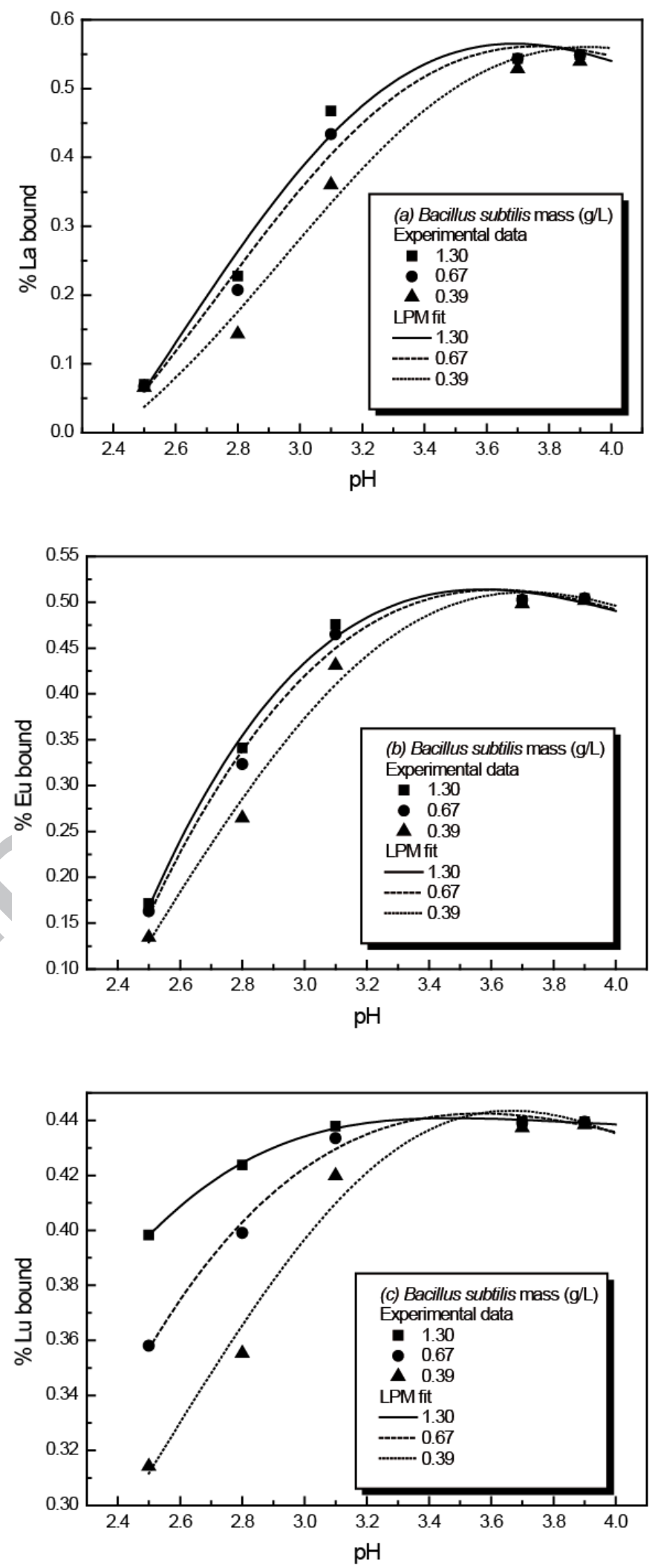

Figure 1. 


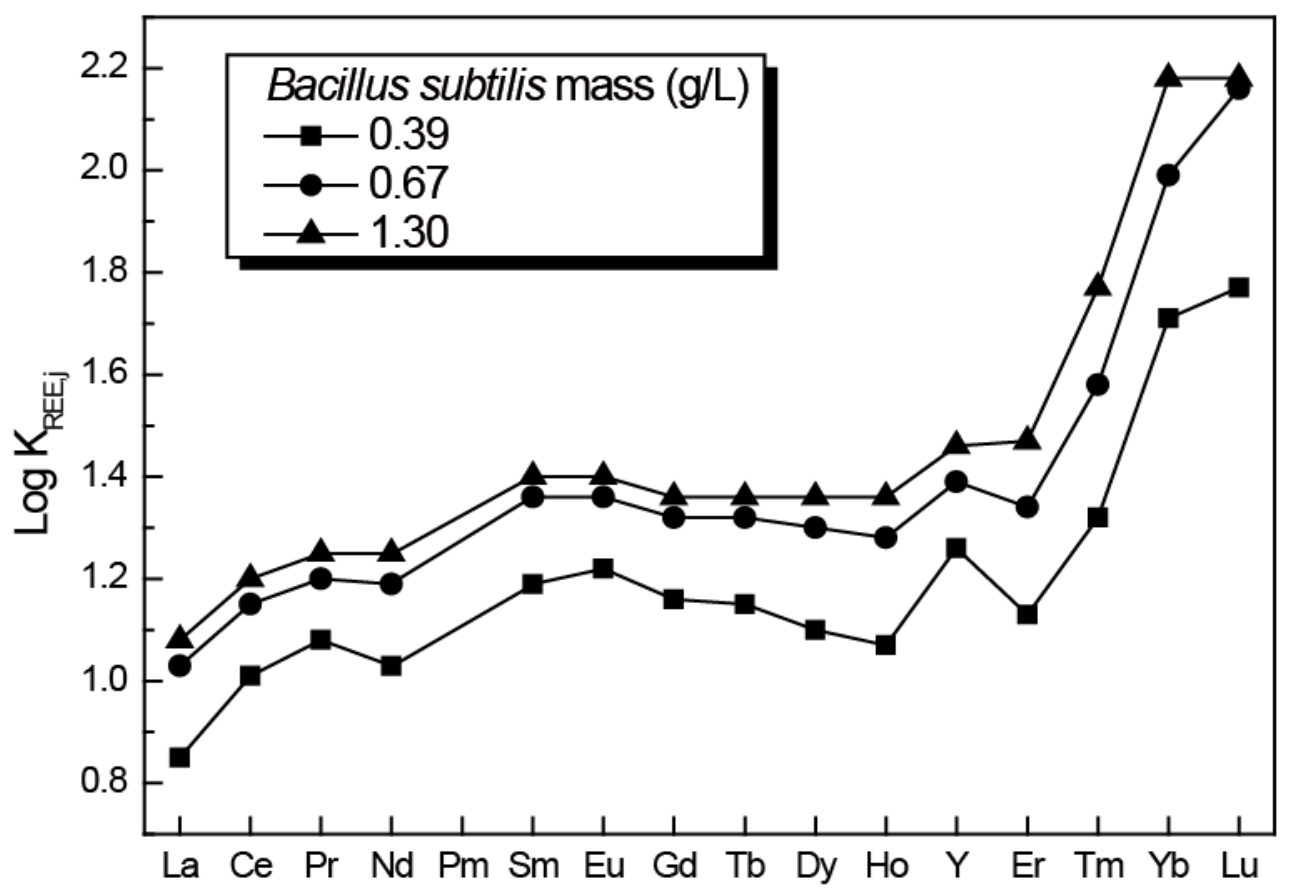

Figure 2

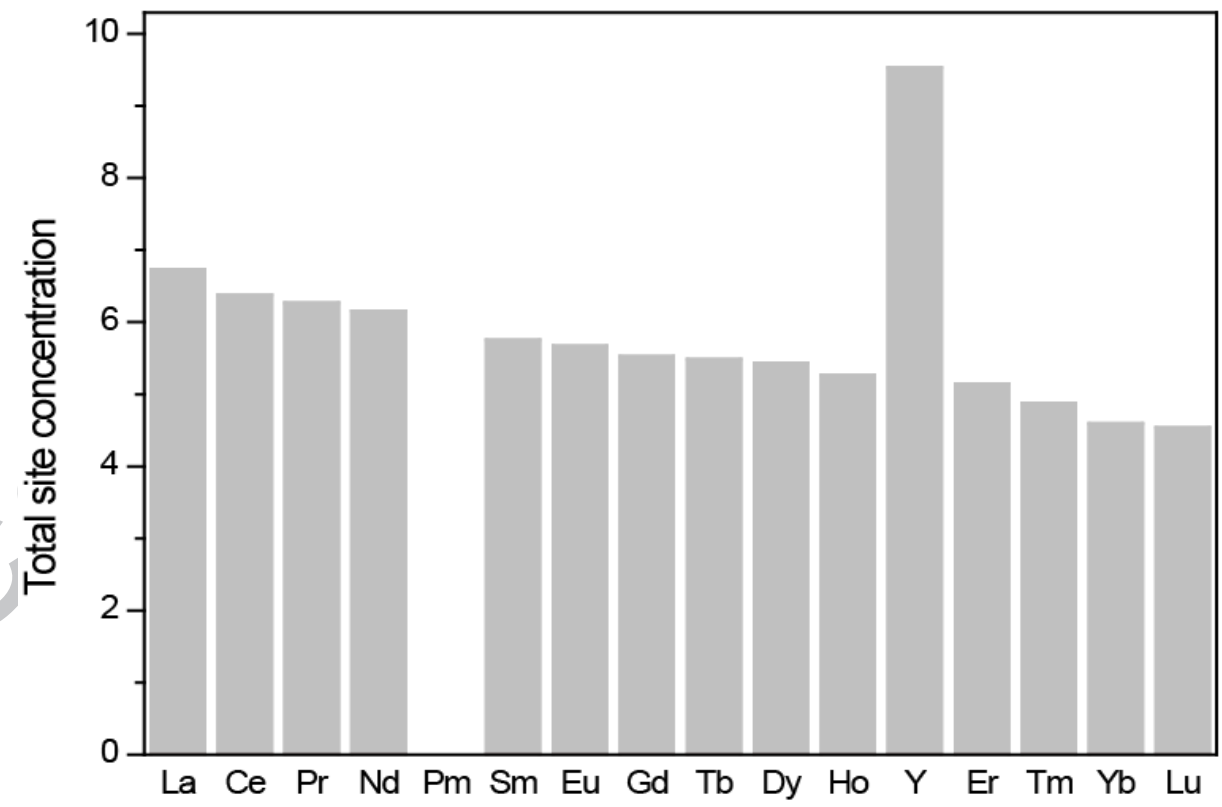

Figure 3 


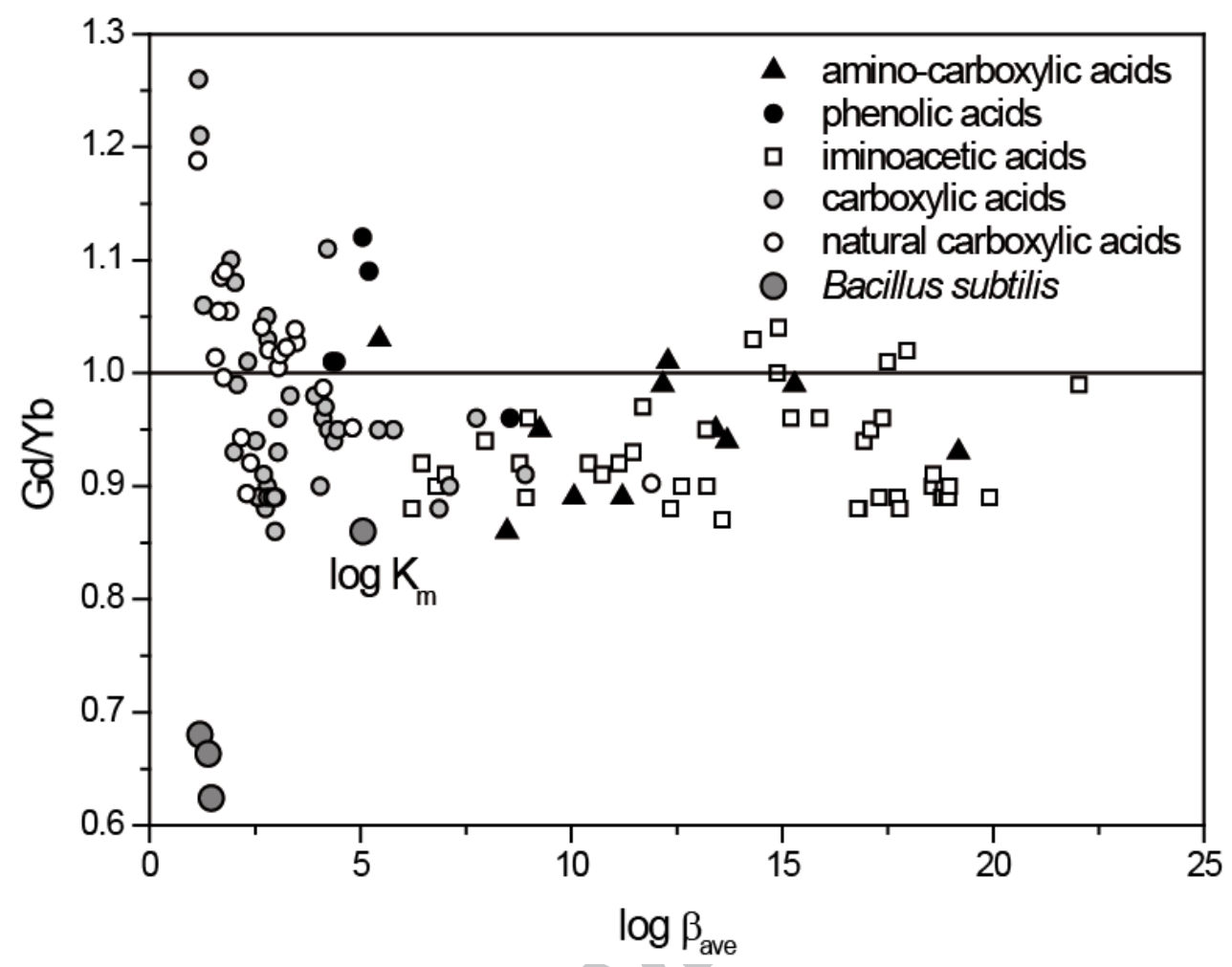

Figure 4 


\section{References}

[1] P. Henderson, Rare earth element geochemistry, Elsevier, Amsterdam, 1984.

[2] R. D. Shannon, Acta Crystallogr. A32 (1976) 751-767.

[3] M. Bau, Contrib. Mineral. Petrol. 123 (1996) 323-333.

[4] S. A. Wood, Chem. Geol. 82 (1990) 159-186.

[5] J. Tang, K. H. Johannesson, Geochim. Cosmochim. Acta 67 (2003) 2321-2339.

[6] R. H. Byrne, B. Li, Geochim. Cosmochim. Acta 59 (1995) 4575-4589.

[7] O. Pourret, M. Davranche, J. Colloid Interface Sci. 395 (2013) 18-23.

[8] A. Dia, G. Gruau, G. Olivié-Lauquet, C. Riou, J. Molénat, P. Curmi, Geochim. Cosmochim. Acta 64 (2000) 4131-4151.

[9] B. Dupré, J. Viers, J.-L. Dandurand, M. Polvé, P. Bénézeth, P. Vervier, J.-J. Braun, Chem. Geol. 160 (1999) 63-80.

[10] O. Pourret, G. Gruau, A. Dia, M. Davranche, J. Molénat, Aquat. Geochem. 16 (2010) 31-59.

[11] O. Pourret, R. E. Martinez, J. Colloid Interface Sci. 330 (2009) 45-50.

[12] O. Pourret, M. Davranche, G. Gruau, A. Dia, Chem. Geol. 243 (2007) 128-141.

[13] R. Marsac, M. Davranche, G. Gruau, A. Dia, Geochim. Cosmochim. Acta 74 (2010) 1749-1761.

[14] Y. Takahashi, X. Châtellier, K. H. Hattori, K. Kato, D. Fortin, Chem. Geol. 219 (2005) 53-67.

[15] T. J. Beveridge, R. J. Doyle, Metal Ions and Bacteria, Wiley, New-York, 1989.

[16] D. Fortin, F. G. Ferris, T. J. Beveridge, Rev. Miner. 35 (1997) 161-180.

[17] Y. Takahashi, T. Hirata, H. Shimizu, T. Ozaki, D. Fortin, Chem. Geol. 244 (2007) 569-583.

[18] S. Markai, Y. Andrès, G. Montavon, B. Grambow, J. Colloid Interface Sci. 262 (2003) 351-361.

[19] P. Brassard, J. R. Kramer, P. V. Collins, Environ. Sci. Technol. 24 (1990) 195201.

[20] A. L. Herbelin, J. C. Westall, FITEQL, A computer program for determination of chemical equilibrium constants from experimental data, Report 99-01, Department of Chemistry, Oregon State University, Corvallis, 1999.

[21] R. E. Martinez, F. G. Ferris, J. Colloid Interface Sci. 243 (2001) 73-80.

[22] J. B. Fein, C. J. Daughney, N. Yee, T. A. Davis, Geochim. Cosmochim. Acta 61 (1997) 3319-3328.

[23] V. R. Phoenix, R. E. Martinez, K. O. Konhauser, F. G. Ferris, Applied and Environmental Microbiology 68 (2002) 4827-4834.

[24] B. T. Ngwenya, M. Magennis, V. Olive, J. F. W. Mosselmans, R. M. Ellam, Environmental Science and Technology 44 (2010) 650-656.

[25] P. Venema, T. Hiemstra, W. H. van Riemsduk, J. Colloid Interface Sci. 181 (1996) 45-59.

[26] S. D. Kelly, K. M. Kemner, J. B. Fein, D. A. Fowle, M. I. Boyanov, B. A. Bunker, N. Yee, Geochim. Cosmochim. Acta 66 (2002) 3855-3871.

[27] G. A. Waychunas, C. C. Fuller, J. A. Davis, J. J. Rehr, Geochim. Cosmochim. Acta 67 (2003) 1031-1043. 
[28] B. T. Ngwenya, J. F. W. Mosselmans, M. Magennis, K. D. Atkinson, J. Tourney, V. Olive, R. M. Ellam, Geochim. Cosmochim. Acta 73 (2009) 3134-3147.

[29] Y. Takahashi, M. Yamamoto, Y. Yamamoto, K. Tanaka, Geochim. Cosmochim. Acta 74 (2010) 5443-5462.

[30] M. I. Boyanov, S. D. Kelly, K. M. Kemner, B. A. Bunker, J. B. Fein, D. A. Fowle, Geochim. Cosmochim. Acta 67 (2003) 3299-3311.

[31] J. C. Westall, J. D. Jones, G. D. Turner, J. M. Zachara, Environ. Sci. Technol. 29 (1995) 951-959.

[32] R. E. Martinez, K. Pedersen, F. G. Ferris, J. Colloid Interface Sci. 275 (2004) 8289.

[33] S. A. Wood, Eng. Geol. 34 (1993) 229-259.

[34] R. E. Martinez, D. S. Smith, E. Kulczycki, F. G. Ferris, J. Colloid Interface Sci. 253 (2002) 130-139.

[35] J. B. Fein, A. M. Martin, P. G. Wightman, Geochim. Cosmochim. Acta 65 (2001) 4267-4273.

[36] D. G. Brookins, in: Aqueous geochemistry of rare earth elements, P. H. Ribbe (Ed.), The Mineralogical Society of America: Washington, 1989, pp 201-225.

[37] G. R. Choppin, D. R. Peterman, Coordin. Chem. Rev. 174 (1998) 283-299.

[38] Y. Takahashi, Y. Minai, S. Ambe, Y. Makide, F. Ambe, T. Tominaga, Sci. Total Environ. 198 (1997) 61-71.

[39] Y. Yamamoto, Y. Takahashi, H. Shimizu, Chem. Lett. 34 (2005) 880-881.

[40] Y. Yamamoto, Y. Takahashi, H. Shimizu, Geochim. Cosmochim. Acta Supplement 1 (2006) A717.

[41] J. E. Sonke, V. J. M. Salters, Geochim. Cosmochim. Acta 70 (2006) 1495-1506.

[42] J. D. Ritchie, E. M. Perdue, Geochim. Cosmochim. Acta 67 (2003) 85-96.

[43] J. C. Stern, J. E. Sonke, V. J. M. Salters, Chem. Geol. 246 (2007) 170-180. 


\section{Highlights:}

- A single binding site was found for REE on Bacillus subtilis at low $\mathrm{pH}$

- Modeling of sorption data by LPM shows REE enrichement on bacteria

- $\quad$ HREE (Tm, Yb, Lu) show strong enrichment pattern on B. subtilis.

LPM modeling suggests carboxylic groups for REE binding on bacteria. 


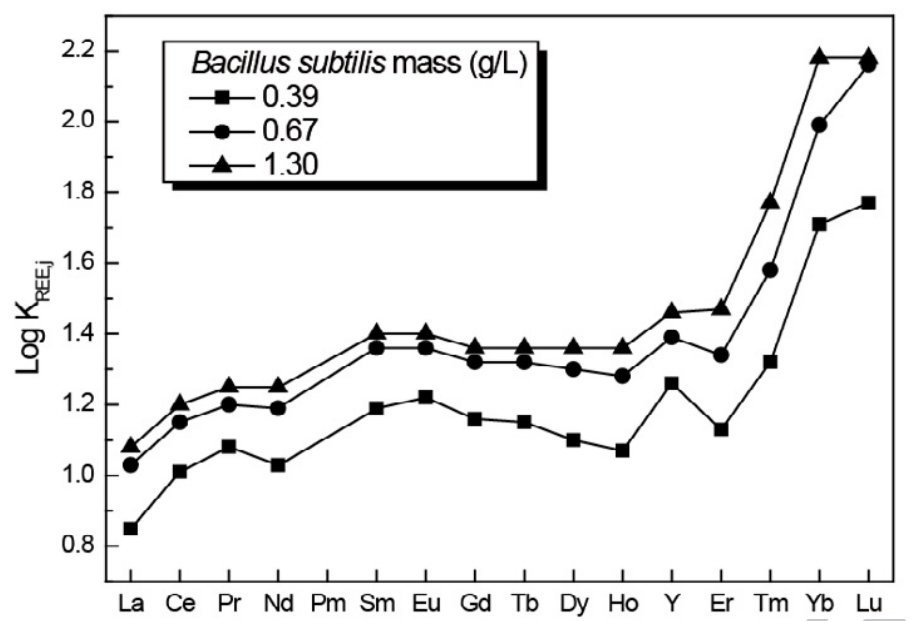

Log KREE pattern showing LREE (Sm, Eu) and HREE (Tm, Yb, Lu) enrichment as a function of increasing Bacillus subtilis biomass 